\title{
EFFECT OF SODIUM HYDROXIDE PRETREATMENT ON CHEMICAL COMPOSITION OF TREATED ACACIA MANGIUM USING RESPONSE SURFACE METHODOLOGY
}

\author{
Rafidah J' ${ }^{1,2}$ *, Mohd-Sahaid K${ }^{1}$, Norliza AR ${ }^{1}$, Aidil $\mathrm{AH}^{3}$ \& Mohd-Farid A ${ }^{2}$ \\ ${ }^{1}$ Faculty of Engineering and Built Environment, Universiti Kebangsaan Malaysia, 43600 Bangi, Selangor, Malaysia \\ ${ }^{2}$ Forest Research Institute Malaysia, 52109 Kepong, Selangor, Malaysia \\ ${ }^{3}$ Faculty of Sciences and Technology, Universiti Kebangsaan Malaysia, 43600 Bangi, Selangor, Malaysia \\ *rafidahjalil@frim.gov.my
}

Submitted February 2020; accepted June 2020

\begin{abstract}
High cellulose biomass is required to produce high yield fermentable sugars to be used as a feedstock for biofuels production. However, the higher lignin content in biomass becomes a hindrance to a high cellulose content biomass raw material production. Therefore, an alkaline pretreatment optimised with sodium hydroxide $(\mathrm{NaOH})$ is necessary to remove lignin. In this study, the optimisation was carried out using response surface methodology and the parameters were set at a temperature range of $70-100{ }^{\circ} \mathrm{C}$, the reaction time of 1-3 hours and $\mathrm{NaOH}$ concentration between $1-10 \% \mathrm{w} / \mathrm{v}$. The samples were analysed to obtain its chemical composition and compared with untreated Acacia mangium. Optimised conditions were achieved at $70{ }^{\circ} \mathrm{C}$ (temperature), 3 hours (reaction time) and $5.50 \% \mathrm{w} / \mathrm{v}(\mathrm{NaOH}$ concentration) with optimized cellulose, hemicellulose and lignin removal content of 47.66, 36.16 and $12.66 \%$ and standard error of $7.90,1.87$ and $3.24 \%$ respectively. In the study, the cellulose content obtained from the $\mathrm{NaOH}$ treated A. mangium had risen to about $20.40 \%$ and had high potential to be used as a feedstock for the production of fermentable sugars.
\end{abstract}

Keywords: Lignocellulosic biomass, central composite design, analysis of variance, thermogravimetric analysis, cellulose content

\section{INTRODUCTION}

Lignocellulosic biomasses are renewable organic raw materials that are easily obtained in large amounts at low prices (Fang et al. 2010, Rawat et al. 2013). It is also part of the agricultural and forestry wastes where the accumulation of unutilised waste causes environmental problems (Gilna \& Khaleel 2011, Falkoski et al. 2012). Short-term cultivation species such as Acacia mangium containing low lignin needs minimal fertiliser for its potential growth and is an important source for raw materials in biofuels production (Chong et al. 2013, Rawat et al. 2013). Since the 1980s, A. mangium plantation has been established in Malaysia with Sarawak having the largest plantation area of around 289,816 ha in 2012 and used mainly for furniture products (Redzuan et al. 2019). Nevertheless, no plantation field was developed in Malaysia for biofuels specifically for bioethanol production as an alternative to petrol.

Cellulose, hemicellulose and lignin make up about $90 \%$ of the dry weight of plant materials
(Irfan et al. 2011). The decomposition of these components into simple sugars, such as glucose and xylose, is accomplished by cellulase and xylanase enzymes during enzymatic reaction (Singh et al. 2011). Cellulose is a linear polymer comprising of glucose linked to $\beta$-1,4-glucosidic bond and hemicellulose is a heteropolysaccharide consisting of $\beta-1,4-$ links polysaccharide with different degrees of substitution (Praveen et al. 2012). Hemicelluloses are commonly found outside the cellulose fibre structures which act as a physical barrier that limits the cellulase enzyme to act on cellulose (Hu et al. 2011). The main challenge in the use of lignocellulosic materials is to convert its structure from complex carbohydrates into monosaccharide. Therefore, pretreatment of lignocellulosic material is crucial to enhance the decomposition of lignocellulose material by hydrolytic enzymes through the breakdown of lignin, hemicelluloses and cellulose bonds for enzymatic hydrolysis purposes (Sendelius 2005, Singh et al. 2011, Isikhuemhen et al. 2014) . 
Pretreatment is also an important step to remove or modify the structure of hemicellulose and lignin, reduce cellulose crystallisation, improve surface area and enhancing the hydrolysis efficiency as well as to improve its porosity (Yang et al. 2010, Irfan et al. 2011, Maeda et al. 2011) by the enzyme during the hydrolysis process for the production of fermentable sugars (Quiroz-castaneda et al. 2009, Rawat et al. 2013). Temperature, chemical concentration and treatment time affect the pretreatment process (Ruffell et al. 2010. Nur Izzati et al. 2013). Generally, after the lignocelluloses are treated, the amount of cellulose composition will increase, while the composition of hemicellulose and lignin will decrease depending on the type of pretreatment used (Sharma et al. 2016).

In general, lignin is a major component in wood that prevents its use as a raw material for biotechnology product development and affects the rate of enzymatic hydrolysis (Maeda et al. 2011, Nur Izzati et al. 2013). Removal of the lignin is possible because of its solubility in alkaline solution. Decomposition of lignin can also reduce unproductive binders between celluloses (Yang et al. 2010). However, the slow decomposition process of lignocellulose material is considered less economical (Ibrahim 2008). Hence, new methods are needed to increase the fermentation of sugar through a combination of chemical and enzymatic hydrolysis processes.

The production of sugar from biomass is an important step in industrial processing, so physical and chemical pretreatment have been widely used to break down lignin bonds and separate cellulose fibres and monomers of hemicellulose components (Quiroz-castaneda et al. 2009). Removal of hemicellulose content also affects the production of fermentable sugars where more hemicellulose is removed and higher fermentable sugars will be produced (Sendelius 2005).

Alkaline pretreatment is one of the best pretreatment for delignification of lignocellulosic biomass (Nur Izzati et al. 2013) which leads to partial delignification, increasing fibre surface area through cellulose swelling and removal of hemicellulose and lignin (Chen et al. 2018). Alkaline pretreatment using sodium hydroxide $(\mathrm{NaOH})$ on oil palm stem eliminates up to $19.8 \%$ of lignin content (Ibrahim 2008).

The conventional way used to optimise a multifactorial method is to resolve one factor at a time, but this is time consuming (Rawat et al. 2013, Saliman et al. 2017). Response surface methodology (RSM) has been adopted to determine the optimised parameter conditions for alkaline pretreatment process (reaction temperature, reaction time and $\mathrm{NaOH}$ concentration) to produce optimised cellulose composition. Thus, RSM is the fastest and easiest way to determine the effects of the various independent variables. Poplar wood pretreated using $\mathrm{NaOH}$ at the optimized conditions of $2.80 \% \mathrm{w} / \mathrm{v}$ concentration, $94{ }^{\circ} \mathrm{C}$ reaction temperature and $60 \mathrm{~min}$ reaction time have increased cellulose composition by $26.15 \%$ (Rawat et al. 2013). The cellulose content of treated rice straw was at approximately $42.01 \%$ with the optimised $\mathrm{NaOH}$ concentration of $2.96 \% \mathrm{w} / \mathrm{v}$ at temperature of $81.79{ }^{\circ} \mathrm{C}$ and 56.66 min reaction time (Kim and Han 2012).

Therefore, the objective of this study was to use RSM to determine the optimum pretreatment conditions to improve chemical composition of $A$. mangium with the purpose to increase the cellulose content and reduce the lignin content. The relationship among different parameters will be analysed to obtain its interacting effects on the overall process.

\section{MATERIALS AND METHODS}

\section{Materials preparation}

The raw materials (Acacia mangium) were obtained from FRIM Research Station, Segamat, Johor. They were cut into chips and samples of $A$. mangium were dried in an oven at $60^{\circ} \mathrm{C}$ to achieve moisture content of less than $10 \%$. The chips were ground to smaller particles with a grinder and sieved with a $250 \mu \mathrm{m}$ mesh filter to obtain uniform $250 \mu \mathrm{m}$ of sample size. The sample then underwent alkaline pretreatment process. Untreated A. mangium was used as a control and reference to the treated A. mangium throughout this study.

\section{Alkaline pretreatment method}

Acacia mangium was treated with a $\mathrm{NaOH}$ solution at a liquid to solid ratio of 1:20. About $20 \mathrm{~g}$ of A. mangium was mixed with $400 \mathrm{ml}$ of $\mathrm{NaOH}$ solution at different concentrations of $\mathrm{NaOH}$ $(1-10 \% \mathrm{w} / \mathrm{v})$ and was treated at different reaction times (1-3 hours) with different reaction temperatures $\left(70-100^{\circ} \mathrm{C}\right)$. The treated samples 
were filtered using a vacuum pump to separate the treated $A$. mangium sample from the liquid medium. Treated A. mangium was washed and rewashed using distilled water to neutralise the samples to $\mathrm{pH} 7$. Lastly, the treated samples were dried in the oven at $60{ }^{\circ} \mathrm{C}$ and further characterised to determine their chemical composition and were compared against the untreated $A$. mangium.

\section{Response surface methodology and central composite design}

Optimisation of alkaline pretreatment of

A. mangium was performed using response surface methodology RSM with central composite design (CCD). Three key factors (temperature, reaction time and $\mathrm{NaOH}$ concentration) with a suitable range were considered based on previous studies in order to obtain optimum parameter conditions. A total of 20 experimental runs with three replicates were conducted (Table 1). A quadratic model was fitted through correlations between responses and independent variables (factors) and a quadratic polynomial equation (equation 1) was used to determine the relationship between these variables (Jaisamut et al. 2013, Siti Sabrina et al. 2014).

$\mathrm{Y}=\mathrm{b}_{0}+\sum \mathrm{b}_{\mathrm{i}} \mathrm{x}_{\mathrm{i}}+\sum \mathrm{b}_{\mathrm{ii}} \mathrm{x}_{\mathrm{i} 2}+\sum \mathrm{b}_{\mathrm{iii}} \mathrm{x}_{\mathrm{i} 3}+\sum \mathrm{b}_{\mathrm{ij}} \mathrm{x}_{\mathrm{i}} \mathrm{x}_{\mathrm{j}}$

where $Y=$ predicted response, $x_{i} x_{j}=$ input variables, $b_{0}=a$ constant, $b_{i}=$ linear coefficient, $b_{\mathrm{ii}}=$ square coefficient, $\mathrm{b}_{\mathrm{iii}}=$ cubic coefficient and $\mathrm{b}_{\mathrm{ij}}=$ interaction coefficient.

\section{Statistical analysis}

Design Expert 8.0.6 was used to develop the model of experiment. The effect of $\mathrm{NaOH}$ concentration on the chemical composition (cellulose, hemicellulose and lignin) of treated A. mangium was analysed using the Analysis of variance (ANOVA). Verification of the predicted value was determined by repeated experiments using the optimum conditions. The percentage error was also calculated based on equation 2 to determine the closeness between the predicted and experimental results.

Table 1 CCD matrix of alkaline treatment of Acacia mangium

\begin{tabular}{cccc}
\hline Run & $\begin{array}{c}\text { Temperature } \\
\left({ }^{\circ} \mathrm{C}\right)\end{array}$ & $\begin{array}{c}\text { Time } \\
(\text { hour })\end{array}$ & $\begin{array}{c}\text { NaOH Concentration } \\
(\% \mathrm{w} / \mathrm{v})\end{array}$ \\
\hline 1 & 85 & 2 & 5.5 \\
2 & 70 & 1 & 1.0 \\
3 & 100 & 3 & 1.0 \\
4 & 100 & 2 & 5.5 \\
5 & 85 & 2 & 10.0 \\
6 & 85 & 2 & 5.5 \\
7 & 70 & 3 & 10.0 \\
8 & 85 & 2 & 5.5 \\
9 & 100 & 1 & 10.0 \\
10 & 100 & 1 & 1.0 \\
11 & 85 & 1 & 5.5 \\
12 & 85 & 2 & 5.5 \\
13 & 85 & 3 & 5.5 \\
14 & 70 & 1 & 10.0 \\
15 & 85 & 2 & 5.5 \\
16 & 85 & 2 & 5.5 \\
17 & 85 & 2 & 1.0 \\
18 & 100 & 3 & 10.0 \\
19 & 70 & 2 & 5.5 \\
20 & 70 & & \\
\hline & & 3.0 & \\
\hline
\end{tabular}


Percentage error $=$

$$
\frac{(\mid \text { Predicted value }- \text { experimental value } \mid)}{\text { Predicted value }} \times 100
$$

\section{Chemical composition characterisation of A. mangium}

Chemical compositions of untreated and treated $A$. mangium were determined using the Thermogravimetric Analysis Method (TGA). About $5 \mathrm{mg}$ of $A$. mangium samples were analysed using TGA. Combustion of samples in triplicates were carried out in the absent of nitrogen gas at a heating rate of $5{ }^{\circ} \mathrm{C} \mathrm{min}^{-1}$ with the temperature range between 25 and $900{ }^{\circ} \mathrm{C}$ (Barneto et al. 2011).

\section{RESULTS AND DISCUSSION}

\section{Characterisation of $A$. mangium for its chemical composition}

The chemical composition (cellulose, hemicellulose and lignin) of A. mangium are important properties to be measured and they served as baseline data to determine the effectiveness of the pretreatment method. The cellulose, hemicellulose and lignin removal content of raw $A$. mangium in comparison with other researchers' findings are shown in Table 2.

It was found that the chemical composition of $A$. mangium used in this study was comparable to the results reported by Raphy et al. (2011). However, the cellulose content was lower and up to $20.61 \%$ difference in comparison with result reported by Yahya et al. (2010), Takazawa et al. (2018) and Mohd Hazim et al. (2018). The large difference of cellulose composition might be due to the different sources of raw material, different age and maturity levels as well as different soil types of the A. mangium plantation. Chemical composition of lignocellulosic materials varies with genetics, age, location, growth conditions, anatomic structure and maturity level of the plant (Hodson et al. 1984, Irfan et al. 2011, Siti Sabrina et al. 2014, Antonopoulou et al. 2015). Lower amount of cellulose composition of A. mangium used in this study was optimised through pretreatment process to increase its cellulose content and to ensure effective accessibility of enzyme during enzymatic hydrolysis process to produce fermentable sugars.

\section{Optimisation of alkaline pretreatment on A. mangium}

The main purpose of pretreatment process is to break down complex carbohydrate polymers, remove or alter the hemicellulose and lignin content, reduce cellulose crystallisation and increase their surface area (Singh et al. 2011, Siti Sabrina et al. 2014). Alkaline pretreatment using $\mathrm{NaOH}$ was chosen for this study as it has been commonly used by previous researchers to remove lignin content and increase surface area (Yoo et al. 2012, Maeda et al. 2013, Uzunlu et al. 2014). Optimisation of alkaline pretreatment of A. mangium was carried out using RSM to obtain optimised cellulose composition.

The experiments evaluated the relationships between temperature, reaction time and concentration of $\mathrm{NaOH}$ with the cellulose, hemicellulose and lignin content. Table 3 shows the ANOVA results of cellulose, hemicellulose and lignin content of treated A. mangium. Model F values of $69.35,282.58$ and 29.39 with $p$ value less than 0.05 for cellulose, hemicellulose and lignin content indicated that this model was significant. The $\mathrm{r}^{2}$ values for cellulose, hemicellulose and lignin content were $0.9842,0.9961$ and 0.9445

Table 2 Various chemical composition of Acacia mangium

\begin{tabular}{cccr}
\hline Cellulose & Hemicellulose & Lignin & Past Research References \\
\hline 39.57 & 47.53 & 19.61 & This study \\
48.10 & 34.20 & 27.20 & (Takazawa et al. 2018) \\
49.84 & 36.14 & 17.23 & (Mohd Hazim et al. 2017) \\
40.00 & - & 17.00 & (Raphy et al. 2011) \\
45.70 & 34.70 & 31.30 & (Yahya et al. 2010) \\
46.75 & 24.85 & 22.35 & (Lim et al. 2011) \\
\hline
\end{tabular}


respectively showing that this model was robust with high fitness and precise (Saliman et al. 2017). A lack of fit value more than 0.05 showed that the model was not significant relative to pure error for cellulose, hemicellulose and lignin content which were $0.0518,0.4136$ and 0.0645 respectively.

The second-degree polynomial models for cellulose, hemicellulose and lignin content are given in equations 3,4 and 5 below.

Cellulose $\left(\mathrm{C}_{1}\right)=$

$44.291+0.030 \mathrm{X}_{1}+3.516 \mathrm{X}_{2}+1.493 \mathrm{X}_{3}+$ $1.670 \times 10^{-4} \mathrm{X}_{1}^{2}-0.332 \mathrm{X}_{2}^{2}+8.238 \times 10^{-3} \mathrm{X}_{3}^{2}-$ $0.017 \mathrm{X}_{1} \mathrm{X}_{2}-0.015 \mathrm{X}_{1} \mathrm{X}_{3}-0.101 \mathrm{X}_{2} \mathrm{X}_{3}$

Hemicellulose $\left(\mathrm{H}_{2}\right)=$ $36.255+0.049 \mathrm{X}_{1}-0.122 \mathrm{X}_{2}-0.349 \mathrm{X}_{3}-$ $1.273 \times 10^{-4} \mathrm{X}_{1}^{2}-0.024 \mathrm{X}_{2}^{2}-4.377 \times 10^{-3} \mathrm{X}_{3}^{2}-$ $7.167 \times 10^{-3} \mathrm{X}_{1} \mathrm{X}_{2}+6.926 \times 10^{-3} \mathrm{X}_{1} \mathrm{X}_{3}-0.046 \mathrm{X}_{2} \mathrm{X}_{3}$

$$
\begin{aligned}
& \text { Lignin }\left(\mathrm{L}_{3}\right)= \\
& -33.750+0.902 \mathrm{X}_{1}+4.792 \mathrm{X}_{2}+1.058 \mathrm{X}_{3}- \\
& 4.756 \times 10^{-3} \mathrm{X}_{1}^{2}-1.375 \mathrm{X}_{2}^{2}+4.198 \times 10^{-3} \mathrm{X}_{3}^{2}+ \\
& 0.024 \mathrm{X}_{1} \mathrm{X}_{2}-6.130 \times 10^{-3} \mathrm{X}_{1} \mathrm{X}_{3}-0.225 \mathrm{X}_{2} \mathrm{X}_{3}
\end{aligned}
$$

where $\mathrm{X}_{1}, \mathrm{X}_{2}$, and $\mathrm{X}_{3}$ are temperature (A), reaction times (B) and concentration of $\mathrm{NaOH}$ (C) respectively.
Based on Table 3 and $\mathrm{F}$ values, temperature and $\mathrm{NaOH}$ concentration had the highest influences on cellulose and hemicellulose contents. However, reaction time and $\mathrm{NaOH}$ concentration had the highest influence on lignin removal content. Figure 1, shows the interaction effect of temperature and $\mathrm{NaOH}$ concentration on cellulose content. When the temperature increased from 70 to $100{ }^{\circ} \mathrm{C}$ with $\mathrm{NaOH}$ concentration was kept constant at $1.00 \%$ $\mathrm{w} / \mathrm{v}$, the cellulose content decreased by $0.41 \%$ ( 51.36 to $51.15 \%$ ) and decreased by $8.31 \%$ (51.88 to $47.57 \%$ ) when $\mathrm{NaOH}$ concentration was increased to $10.00 \% \mathrm{w} / \mathrm{v}$.

If temperature and reaction time was kept constant at $70{ }^{\circ} \mathrm{C}$ and 3 hours respectively, the increase in $\mathrm{NaOH}$ concentration (1.00 to $10.00 \%$ $\mathrm{w} / \mathrm{v}$ ) increased the cellulose content by $1.01 \%$. Based on these findings it showed that at higher temperature and higher concentration of $\mathrm{NaOH}$, the cellulose was likely to dissolve. Due to the high concentrations of alkaline, the surface topography of the biomass was damaged and soluble cellulose were lost during neutralisation step, leaving behind less amount of cellulose (Siti Sabrina et al. 2014, Oushabi et al. 2017). In addition, normal alkaline pretreatment is performed at lower temperatures but longer reaction time is needed compared with just a few minutes for acid pretreatment (Jaisamut et al. 2013, Antonopoulou et al. 2015).

Like cellulose, temperature and $\mathrm{NaOH}$

\begin{tabular}{|c|c|c|c|c|c|c|}
\hline \multirow{2}{*}{ Source } & \multicolumn{2}{|c|}{ Cellulose } & \multicolumn{2}{|c|}{ Hemicellulose } & \multicolumn{2}{|c|}{ Lignin } \\
\hline & F-value & $\mathrm{p}$-value & F-value & $\mathrm{p}$-value & F-value & p-value \\
\hline Model & 69.35 & $<0.0001$ & 282.58 & $<0.0001$ & 29.39 & $<0.0001$ \\
\hline $\mathrm{A}$ & 230.14 & $<0.0001$ & 690.35 & $<0.0001$ & 117.08 & $<0.0001$ \\
\hline B & 11.00 & 0.0078 & 1355.60 & $<0.0001$ & 0.83 & 0.3831 \\
\hline $\mathrm{C}$ & 32.87 & 0.0002 & 233.69 & $<0.0001$ & 16.04 & 0.0025 \\
\hline $\mathrm{A}^{2}$ & 0.12 & 0.7313 & 0.26 & 0.6195 & 11.85 & 0.0063 \\
\hline $\mathrm{B}^{2}$ & 9.42 & 0.0119 & 0.18 & 0.6813 & 20.25 & 0.0011 \\
\hline $\mathrm{C}^{2}$ & 2.38 & 0.1538 & 2.52 & 0.1438 & 0.31 & 0.5872 \\
\hline $\mathrm{AB}$ & 16.19 & 0.0024 & 10.76 & 0.0083 & 4.37 & 0.0630 \\
\hline $\mathrm{AC}$ & 253.94 & $<0.0001$ & 203.58 & $<0.0001$ & 6.35 & 0.0304 \\
\hline $\mathrm{BC}$ & 51.54 & $<0.0001$ & 40.11 & $<0.0001$ & 36.81 & 0.0001 \\
\hline Lack of fit & 4.96 & 0.0518 & 1.23 & 0.4136 & 3.12 & 0.0645 \\
\hline
\end{tabular}
concentration had highest influence on

Table 3 Statistical analysis (ANOVA) of cellulose, hemicellulose and lignin (CHL) content of treated A. mangium

$\mathrm{A}=$ temperature, $\mathrm{B}=$ reaction time, $\mathrm{C}$ = concentration of $\mathrm{NaOH}$ 

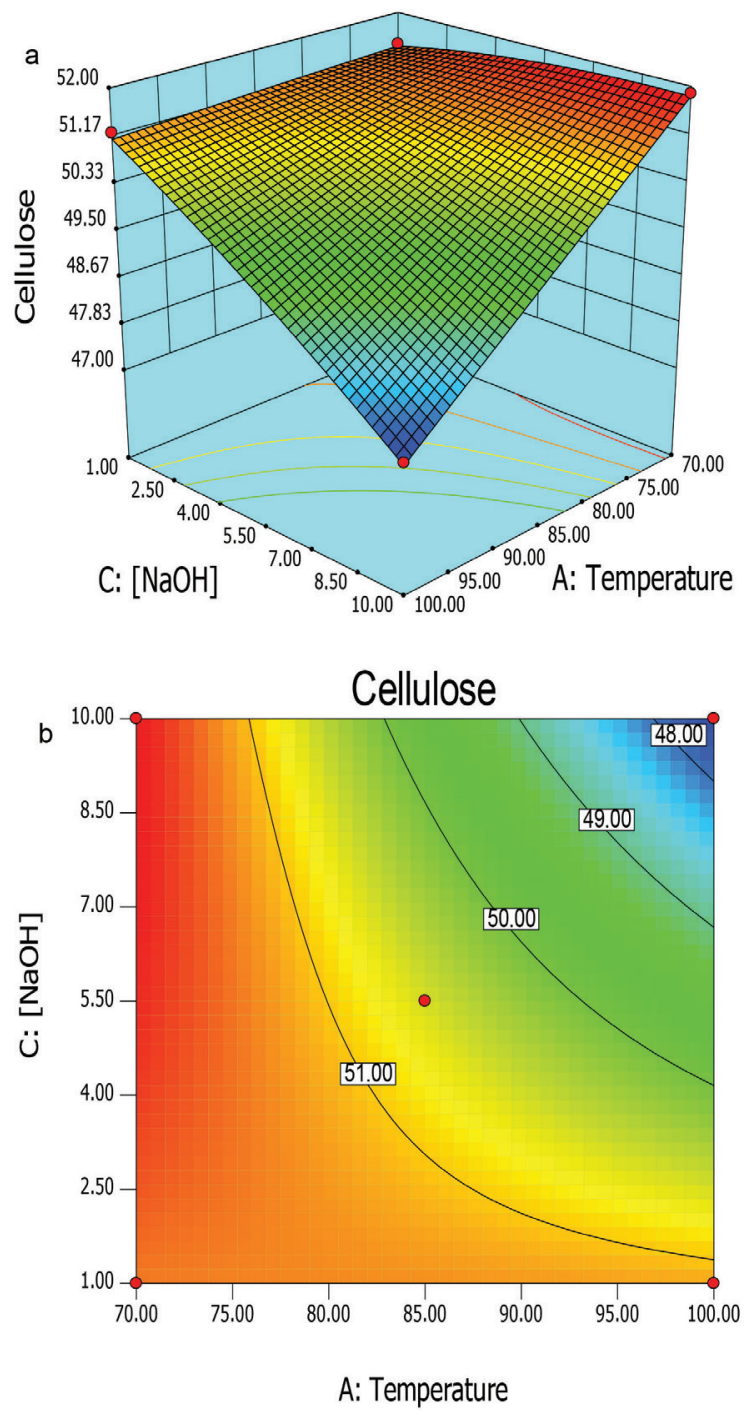

Figure 13 D surface plot (a) and interaction effect (b) between factors $\mathrm{A}$ and $\mathrm{C}$ on cellulose content of treated $A$. mangium

hemicellulose content (Figure 2). Interactions between temperature and $\mathrm{NaOH}$ concentration greatly influenced the hemicellulose content. When the temperature increased from 70 to $100{ }^{\circ} \mathrm{C}$ with $\mathrm{NaOH}$ concentration of $1.00 \%$ $\mathrm{w} / \mathrm{v}$, it showed an increase of hemicellulose content by $2.41 \%$ (36.99 to $37.88 \%$ ) compared with $6.19 \%$ increase ( 36.53 to $38.79 \%$ ) when $\mathrm{NaOH}$ concentration was at $10.00 \% \mathrm{w} / \mathrm{v}$. If the temperature was set to $70{ }^{\circ} \mathrm{C}$, an increase in $\mathrm{NaOH}$ concentration ( 1.00 to $10.00 \% \mathrm{w} / \mathrm{v}$ ) would have resulted in a decrease in hemicellulose content by $1.24 \%$ (36.99 to $36.53 \%$ ). It was found that, at lower temperature $\left(70{ }^{\circ} \mathrm{C}\right)$ and higher concentration of $\mathrm{NaOH}(10.00 \% \mathrm{w} / \mathrm{v})$, decrease of hemicellulose content and increase of cellulose content were observed. Treatment temperature was an important factor that affected pretreatment either through biological or chemical process (Saliman et al. 2017).

Figure 3 shows the interaction effect between reaction time and $\mathrm{NaOH}$ concentration that strongly influenced the removal of lignin content. When the reaction time had increased from 1 to 3 hours with $\mathrm{NaOH}$ concentration at $1.00 \% \mathrm{w} / \mathrm{v}$, it showed an increase of lignin content removal by $14.01 \%$ (11.56 to $13.18 \%$ ) compared with $15.45 \%$ decrease (15.60 to $13.19 \%$ ) when $\mathrm{NaOH}$ concentration was kept at $10.00 \% \mathrm{w} / \mathrm{v}$. If the reaction time was set to 3 hours, the increase in $\mathrm{NaOH}$ concentration $(1.00$ to $10.00 \% \mathrm{w} / \mathrm{v})$ resulted in a very small removal of lignin content by $0.08 \%$ (13.18 to $13.19 \%)$. As for lignin content, comparison of 

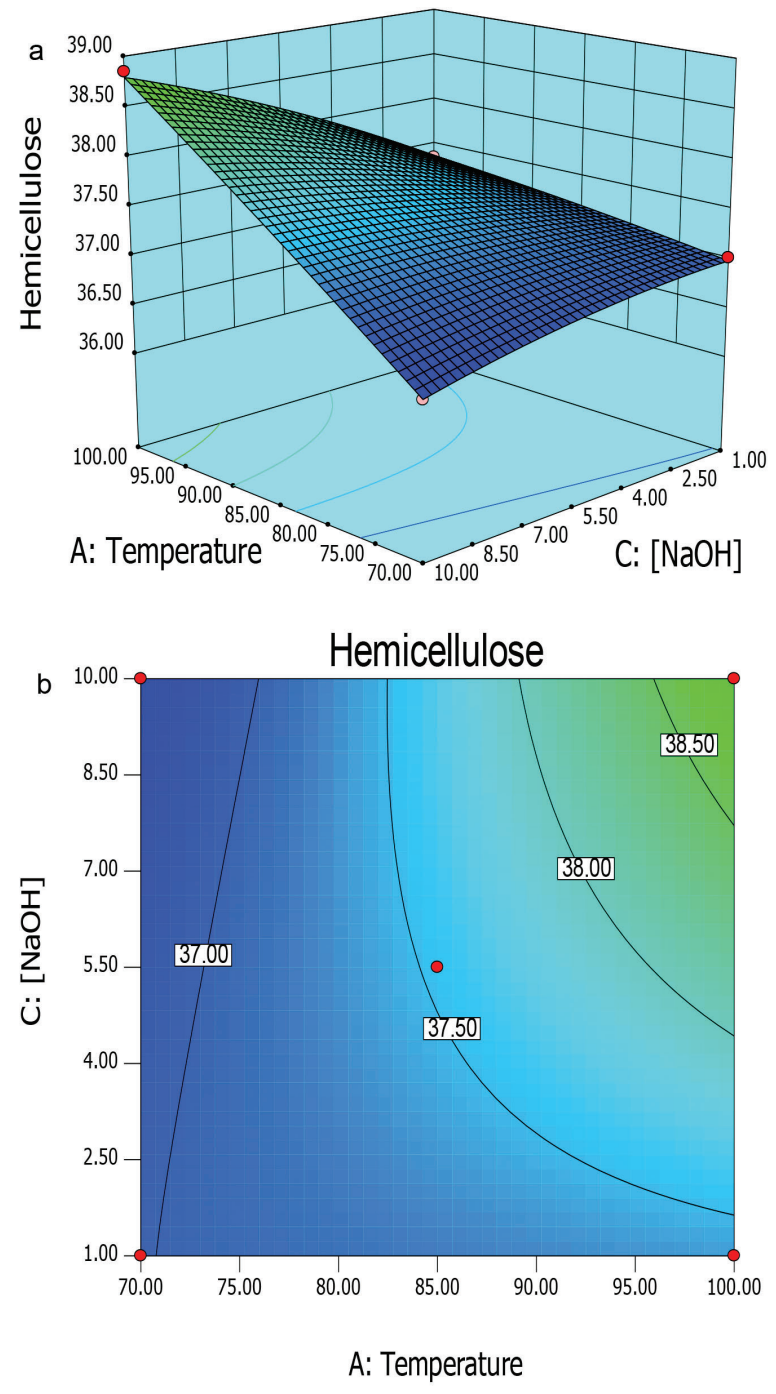

Figure 2 3D surface plot (a) and interaction effect (b) between factors $\mathrm{A}$ and $\mathrm{C}$ on hemicellulose content of treated A. mangium

factors for interaction effects showed that lower temperatures $\left(70{ }^{\circ} \mathrm{C}\right.$ ) and shorter time (1 hour) at lower alkali concentrations $(1.00 \% \mathrm{v} / \mathrm{v})$ could eliminate more lignin.

Generally, RSM model predicted the cellulose, hemicellulose and lignin removal content at $51.75,36.85$ and $13.03 \%$ respectively were achieved at optimum conditions of $70{ }^{\circ} \mathrm{C}$ (temperature), 3 hours reaction time and $5.50 \%$ $\mathrm{w} / \mathrm{v}$ concentration of $\mathrm{NaOH}$. The validation of results were performed using optimal conditions and the experimental values for cellulose, hemicellulose and lignin obtained were 47.66, 36.16 and $12.66 \%$ respectively, with predicted errors of $7.90,1.87$ and $3.24 \%$ respectively. It showed that the experimental results were in good agreement with the predicted values by the proposed model with less than $10 \%$ error.
Among those three factors, $\mathrm{NaOH}$ concentration had the highest influence on the increase of cellulose content and decreas in the lignin content. The major role of $\mathrm{NaOH}$ in the pretreatment was to degrade lignin by breaking up the polymer structure and increased in the biomass porosity (Irfan et al. 2011). Optimum $\mathrm{NaOH}$ concentration of $5.50 \% \mathrm{w} / \mathrm{v}$ showed that RSM could help in reducing the amount of chemical consumption and thus allowed operations at lower temperature $\left(70^{\circ} \mathrm{C}\right)$ instead of $100^{\circ} \mathrm{C}$ that resulted in reduction of production cost and energy consumption. This finding was found agreeable with result obtained by Anita et al. (2019) which only used $1.10 \%$ acid concentration instead of $1.50 \%$ to treat oil palm empty fruit bunch at fastest reaction time ( $3 \mathrm{~min}$ ) when RSM was applied. 

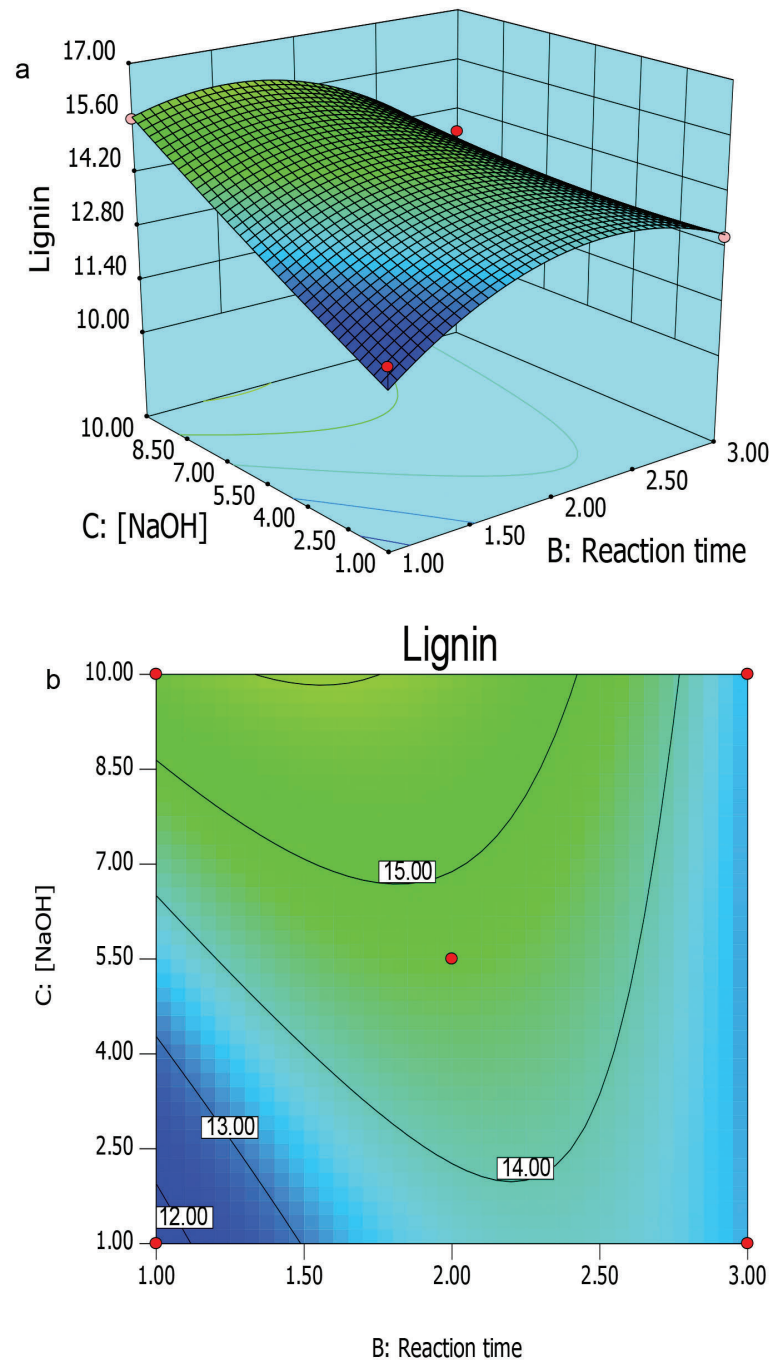

Figure 3 3D surface plot (a) and interaction effect (b) between factors $\mathrm{B}$ and $\mathrm{C}$ on lignin removal content of treated $A$. mangium

Effect of alkaline treated $A$. mangium on cellulose, hemicellulose and lignin content

The optimum chemical composition of cellulose, hemicellulose and lignin content in the treated A. mangium was compared with untreated A. mangium to determine the effectiveness of the pretreatment process on lignin and hemicellulose removal (Table 4). The results showed that pretreatment using alkali $(\mathrm{NaOH})$ was able to reduce lignin content by $35.44 \%$. Alkaline pretreatment increased cellulose content by $20.44 \%$ and reduced hemicellulose content by $23.92 \%$. The alkaline treatment on lignocellulose materials had caused swelling of the biomass structure, increased surface area, reduced polymerisation and crystallisation, disrupted bond formation between lignin and carbohydrate as well as disrupted the lignin structure (Sun \& Cheng 2002, Irfan et al. 2011).

Cellulose content of oil palm frond increased by $46.71 \%$ and the lignin content decreased by $31.53 \%$ after being treated with alkali at $100{ }^{\circ} \mathrm{C}$ for 58.31 min with a $\mathrm{NaOH}$ concentration of $4.42 \%$ w/v (Siti Sabrina et al. 2014). Poplar wood cellulose and hemicellulose content increased by 26.15 and $14.20 \%$ and lignin removal content decreased by $12.70 \%$ after treatment with $\mathrm{NaOH}$ at a concentration of $2.80 \% \mathrm{w} / \mathrm{v}$, at $94{ }^{\circ} \mathrm{C}$ for one hour reaction time (Rawat et al. 2013). Meanwhile, lignin content of wheat straw was reduced by $62.50 \%$ after treatment with alkali at an optimum temperature of $80{ }^{\circ} \mathrm{C}$, reaction time of 39 min using a mixture of $0.18 \mathrm{~g} \mathrm{NaOH}$ and $0.016 \mathrm{~g}$ lime per gram of raw material (rice straw) (Jaisamut et al. 2013). Table 5 shows 
Table 4 Chemical composition of untreated and treated A. mangium

\begin{tabular}{lccc}
\hline \multirow{2}{*}{ Raw material } & \multicolumn{3}{c}{ Chemical composition (\%) } \\
\cline { 2 - 4 } & Cellulose & Hemicellulose & Lignin \\
\hline A. mangium (untreated) & $39.57[0.10]$ & $47.53[0.20]$ & $19.61[0.69]$ \\
A. mangium (treated) & $47.66[0.20]$ & $36.16[0.11]$ & $12.66[0.61]$ \\
Per cent difference & +20.44 & -23.92 & -35.44 \\
\hline
\end{tabular}

$(+)$ = increase; $(-)$ = decrease; $[$ ] = standard deviation

Table 5 Comparison of chemical composition of lignocellulosic biomass treated with alkaline $(\mathrm{NaOH})$

\begin{tabular}{|c|c|c|c|c|c|c|c|}
\hline \multirow{2}{*}{ Raw material } & \multicolumn{3}{|c|}{ Before treatment } & \multicolumn{3}{|c|}{ After treatment } & \multirow{2}{*}{ References } \\
\hline & $\mathrm{C}$ & $\mathrm{H}$ & $\mathrm{L}$ & $\mathrm{C}$ & $\mathrm{H}$ & $\mathrm{L}$ & \\
\hline A. mangium & 39.57 & 47.53 & 19.61 & 47.66 & 36.16 & 12.66 & This study \\
\hline Sugarcane baggase & 39.70 & 28.00 & 23.02 & 55.10 & 18.10 & 8.70 & (Sornlake et al. 2017) \\
\hline Sugarcane baggase & 52.80 & 19.10 & 22.10 & 59.20 & 22.30 & 11.40 & (Visser et al. 2013) \\
\hline Oil palm frond & 28.71 & 26.02 & 37.63 & 42.12 & 31.93 & 26.05 & (Siti Sabrina et al. 2014) \\
\hline Poplar wood & 45.50 & 16.20 & 26.80 & 57.14 & 18.50 & 14.10 & (Rawat et al. 2013) \\
\hline $\begin{array}{l}\text { Mix wheat straw \& } \\
\text { cotton stalk }\end{array}$ & 38.50 & 22.00 & 18.95 & 40.02 & 15.06 & 10.25 & (Sharma et al. 2016) \\
\hline
\end{tabular}

$\mathrm{C}=$ cellulose, $\mathrm{H}=$ hemicelluloses, $\mathrm{L}=$ lignin

the chemical composition of various types of biomass in comparison with findings obtained in this study. The comparison was made for the lignocellulosic biomass before and after the pretreatment with $\mathrm{NaOH}$.

The effect of pretreatment varies from one biomass to another depending on its chemical composition and morphology structure (Dar \& Phutela 2019). Besides, pretreated biomass demands less fermentation time and low energy consumption during fermentable sugars production as compared with untreated biomass (Chen et al. 2018). Due to this reason, it was important to firstly determine the optimised condition in order to get the optimum product yield at low production cost. Alkaline pretreatment using $\mathrm{NaOH}$ significantly affected the removal of lignin and hemicellulose contents which up to 36.00 and $44.90 \%$ respectively (Antonopoulou et al. 2015). Up to $27.40 \%$ of lignin was removed after pretreatment of oil palm mesocarp fibre at temperature of $70{ }^{\circ} \mathrm{C}$ for two hours using $6.00 \% \mathrm{w} / \mathrm{v} \mathrm{NaOH}$ concentration (Nur Izzati et al. 2013). Results from this study showed almost similar observations with other researchers although different types of lignocellulosic biomass materials were used.

\section{CONCLUSIONS}

Alkaline pretreatment is the best way to get rid of lignin thus increases cellulose content. Optimised conditions of alkaline pretreatment was achieved at $70{ }^{\circ} \mathrm{C}, 3$ hours reaction time by using $5.50 \%$ $\mathrm{w} / \mathrm{v} \mathrm{NaOH}$ concentration yielding an increase in cellulose content by $20.44 \%$ and a decrease in hemicellulose and lignin contents by 23.92 and $35.44 \%$ respectively. The ANOVA results indicated that the model and all independent parameters were statistically significant at $95 \%$ of confidence level. Besides, alkaline pretreatment of $A$. mangium shown to be predictable with desirability of 0.93 that was able to increase the amount of cellulose. Adoption of RSM to determine the optimum chemical composition helps in reduction of the pretreatment cost at the early processing stage. This is achieved when RSM managed to identify the desirable optimum conditions thus obtaining the optimised yield of fermentable sugars during enzymatic hydrolysis process.

\section{ACKNOWLEDGEMENTS}

The authors wished to thank University Kebangsaan Malaysia for the Research University 
Grant (FRGS/2/2013/TK05/UKM/02/1 and GUP 2016-006), Jabatan Perkhidmatan Awam of Malaysia and Forest Research Institute Malaysia for their financial and material support for this research.

\section{REFERENCES}

Anita SH, Fitria F, Solihat NN et al. 2019. Optimization of microwave-assisted oxalic acid pretreatment of oil palm empty fruit bunch for production of fermentable sugars. Waste and Biomass Valorization 11: 2673-2687.

Antonopoulou G, Dimitrellos G, Beobide AS et al. 2015. Chemical pretreatment of sunflower straw biomass: the effect on chemical composition and structural changes. Waste and Biomass Valorization 6: 733-746.

Barneto AG, Hernandez RB \& Berenguer JM. 2011. Thermogravimetric characterization of eucalyptus wood. O PAPEL 72: 53-56.

Chen J, Adjalle K, Barnabe S et al. 2018. Mechanical and thermal pretreatment processes for increasing sugar production from woody biomass via enzymatic hydrolysis. Waste and Biomass Valorization 10: 2057 2065.

Chong EWN, Liew KC \& Phiong SK. 2013. Preliminary study on organosolv pulping of Acacia hybrid. Journal of Forest Science 29: 125-130.

Dar RA \& Phutela UG. 2019. Enzymatic and hydrothermal pretreatment of newly isolated Spirulina subsalsa BGLR6 biomass for enhanced biogas production. Waste and Biomass Valorization 11: 3639-3651.

Falkoski DL, Guimaraes VM, De Almeida MN et al. 2012. Characterization of cellulolytic extract from Pycnoporus sanguineus PF-2 and its application in biomass saccharification. Applied Biochemistry and Biotechnology 166: 1586-1603.

FANG H, ZhaO C \& SONG XY. 2010. Optimization of enzymatic hydrolysis of steam exploded corn stover by two approaches: response surface methodology or using cellulase from mixed cultures of Trichoderma reesei RUT-C30 and Aspergillus niger NL02. Bioresource Technology 101: 4111-4119.

Gilna VV \& Khaleel M. 2011. Cellulase enzyme activity of Aspergillus fumigatus from mangrove soil on lignocellulosic substrate. Recent Research in Science and Technology 3: 132-134.

Hu J, Arantes V \& Sadder JN. 2011. The enhancement of enzymatic hydrolysis of lignocellulosic substrates by the addition of accessory enzymes such as xylanase: is it an additive or synergistic effect? Biotechnology for Biofuels 4: 36 https://doi.org/10.1186/1754-68344-36.

Hodson RE, Christian RR \& Maccubbin AE. 1984. Lignocellulose and lignin in the salt marsh grass Spartina alterniflora: initial concentrations and shortterm, post-depositional changes in detrital matter. Marine Biology 81: 1-7.

Iвrahim CO. 2008. Development of applications of industrial enzymes from Malaysian indigenous microbial sources. Bioresource Technology 99: 45724583.
Irfan M, Gulsher M, Abbas S et al. 2011. Effect of various pretreatment conditions on enzymatic saccharification. Songklanakarin Journal of Science and Technology 33: 397-404.

Isikhuemhen OS, Mikiashvili NA, Senwo ZN et AL. 2014. Biodegradation and sugar release from canola plant biomass by selected white rot fungi. Advances in Biological Chemistry 4: 395-406.

Jaisamut K, Paulova L, Patakova P et al. 2013. Optimization of alkali pretreatment of wheat straw to be used as substrate for biofuels production. Plant Soil Environment 59: 537-542.

KIM I \& HAN JI. 2012. Optimization of alkaline pretreatment conditions for enhancing glucose yield of rice straw by response surface methodology. Biomass and Bioenergy 46: 210-217.

Lim SC, Gan KS \& Tan YE. 2011. Properties of A. mangium Planted in Peninsular Malaysia: ITTO Project on Improving Utilization and Value Adding of Plantation Timbers from Sustainable Sources in Malaysia. Project No. PD 306/04 (1). Forest Research Institute Malaysia, Kepong.

Maeda RN, Serpa VI, Rocha VAL et al. 2011. Enzymatic hydrolysis of pretreated sugar cane bagasse using Penicillium funiculosum and Trichoderma harzianum cellulases. Process Biochemistry 46: 1196-1201.

Maeda RN, Barcelos CA, Santa Anna LMM et al. 2013. Cellulase production by Penicillum funiculosum and its application in the hydrolysis of sugar cane bagasse for second generation ethanol production by fed batch operation. Journal of Biotechnology 163: 38-44.

Mohd-Hazim MA, Mohd-Sukhairi MR, Mazlan M et al. 2017. Chemical composition of small diameter wild Acacia mangium species. Asian Research Publishing Network Journal of Engineering and Applied Sciences 12: 2698-2702.

Nur-Izzati I, Jamaliah MJ, Shuhaida H et al. 2013. Sodium hydroxide pretreatment and enzymatic hydrolysis of oil palm mesocarp fiber. International Journal of Chemical Engineering and Applications 4: 101-105.

Oushabi A, Sair S, Oudrhiri HF, Abboud Y et al. 2017. The effect of alkali treatment on mechanical, morphological and thermal properties of date palm fibers (DPFs): study of the interface of DPFe Polyurethane composite. South African Journal of Chemical Engineering 23: 116-123.

Praveen K, Usha KY, Shanthi B et al. 2012. Production of cellulolytic enzymes by a mushroom - Stereum ostrea. International Journal of Research in Biochemistry and Biophysics 2: 1-4.

Quiroz-Castaneda RE, Balcazar-Lopez E, Dantan-Gonzalez E ET AL. 2009. Characterization of cellulolytic activities of Bjerkandera adusta and Pycnoporus sanguineus on solid wheat straw medium. Electronic Journal of Biotechnology 12: 1-8.

Raphy Kmm, Anoop EV, Aruna P et al. 2011. Provenance variation in wood chemical properties of Acacia mangium wild and Acacia auriculiformiscunn., grown in a wet humid site in Thrissur district of Kerala, South India. Journal Indian Academy Wood Science 8: 120-123.

Rawat R, Kumbhar BK \& Tewari L. 2013. Optimization of alkali pretreatment of bioconversion of poplar (Populus deltoides) biomass into fermentable sugars 
using response surface methodology. Industrial Crops and Products 44: 220-226.

RedZuan MSJ, Paridah MT, ANWAR UMK et aL. 2019. Effects of surface pretreatment on wettability of Acacia mangium wood. Journal of Tropical Forest Science 31: 249-258.

Ruffell J, Levie B, Helle S et al. 2010. Pretreatment and enzymatic hydrolysis of recovered fibre for ethanol production. Bioresource Technology 101: 2267-2272.

Saliman MAR, Zaidon A, Bakar ES et al. 2017. Response surface methodology model of hydrothermal treatment parameters on decay resistance of oil palm wood. Journal of Tropical Forest Science 29: 318-324.

Sendelius J. 2005. Steam pretreatment optimisation for sugarcane bagasse in bioethanol production. MSc thesis, Lund University, Sweden.

Sharma S, Sharma V \& Kuila A. 2016. Cellulase production using natural medium and its application on enzymatic hydrolysis of thermo chemically pretreated biomass. 3 Biotech 6: 139 https://link.springer.com/ article/10.1007/s13205-016-0465-z.

Singh A, Tuteja S, Singh M et al. 2011. Enhanced saccharification of rice straw and hull by microwavealkali pretreatment and lignocellulolytic enzyme production. Bioresource Technology 102: 1773-1782.

Siti Sabrina MS, Roshanida AR, Rosli MI et al. 2014. Optimization of alkaline pretreatment conditions of oil palm fronds in improving the lignocelluloses contents for reducing sugar production. Romanian Biotechnological Letters 19: 9006-9018.

Sornlake W, Rattanaphanjak P, Champreda V et al. 2017. Characterization of cellulolytic enzyme system of Schizophyllum commune mutant and evaluation of its efficiency on biomass hydrolysis. Bioscience, Biotechnology and Biochemistry 81: 1289-1299.
Sun Y \& Cheng J. 2002. Hydrolysis of lignocellulosic materials for ethanol production: a review. Bioresource Technology 83: 1-11.

Takazawa R, Yamauchi H, Shibutani S et al. 2018. Changes of moisture content and chemical composition of wood chips during the steaming process in the production of medium density fibreboard. Mokuzai Gakkaishi 64: 205-212.

Uzunlu N, Hosgun EZ \& Bozan B. 2014. Optimization of alkaline pretreatment for enzymatic saccharification of poppy stalks. Bioresources 9: 2824-2834.

Visser EM, Falkoski DL, De-Almeida MN et al. 2013. Production and application of an enzyme blend from Chrysoporthe cubensis and Penicilium pinophilum with potential for hydrolysis of sugarcane bagasse. Bioresource Technology 144: 587-594.

Yahya R, Sugiyama J, Silsia D et al. 2010. Some anatomical features of an Acacia hybrid, A. mangium and A. auriculiformis grown in Indonesia with regard to pulp yield and paper strength. Journal of Tropical Forest Science 22: 343-351.

YANG M, Li W, LiU B ET AL. 2010. High-concentration sugars production from corn stover based on combined pretreatments and fed-batch process. Bioresource Technology 101: 4884-4888.

Yoo HY, Kim SB, Choi HS, Kim K, Park C \& Kim SW. 2012. Optimization of sodium hydroxide pretreatment of canola agricultural residues for fermentable sugar production using statistical method. Pp 175-179 in International Conference on Future Environment and Energy IPCBEE Vol. 28. 26-28 February 2012, Singapore. 